\title{
A HATÁRON ÁTNYÚLÓ AGGLOMERÁCIÓK TURIZMUSÁNAK TÍPUSAI
}

\author{
Dr. Ph.D. Székely Andrea \\ főiskolai docens, Szegedi Tudományegyetem Mémőki Kar, Szeged
}

\section{SUMMARY}

The new borders of Hungary in 1920 cut cities and agglomerations inducing their fallback, but the new situation favoured the creation of new functional centers. The closed boundaries after World War II resulted the development of spatial structures inside the national borders. At the same time, in Western Europe border urban areas organic development started, and they shaped cross-border agglomerations. The soundest example is the French-Belgian Lille cross-border metropolis. After the political changes, the cross-border cooperation based on real common socio-economic interest has become possible in Hungary. This processus is encouraged by the EU through its regional (Interreg, Espon) and urban (Urban, Urbact) programs. The analysis of cross-border agglomerations may be one of the axes of the Hungarian regional researches in the near future.

\section{BEVEZETÉS}

Az első világháborút követő határkijelölés Magyarország „szélein” városokat, vonzáskörzeteket vágott szét, mely az érintett városok, régiók fejlödésbeli megtorpanását, lemaradását okozta, de az ưj helyzet új központok kialakulásával is együtt járt. A határok zártsága a második világháborút követöen is a térstruktúrák országhatárokon belüli fejlödéséhez vezetett. Ugyanakkor Nyugat-Európában az átjárhatóbb határoknak (is) köszönhetöen szerves fejlődésnek indultak a határmentén található városok, s számos esetben egymással együttmüködve közös városi agglomerációkká fejlődtek. A határon átnyúló agglomeráció sokat vizsgált példảja a Franciaország/Belgium határmezsgyéjén található Lillei agglomeráció.

A rendszerváltás után Magyarországon is lehetöség nyílt a határ két oldalán fekvő régiók, városok szorosabb együttmüködésére a közös társadalmi, gazdasági érdekek mentén. Ezt a folyamatot az Európai Unió regionális politikája is támogatja regionális (Interreg, Espon) és városi (Urban, Urbact) programokon keresztül. A határon átnyúló városkörnyéki és városközi terek vizsgálata jelentheti a hazai regionális kutatások egyik jövöbeni irányzatát.

A tanulmány felépítése a következő: Az első részben a téma elméleti hátterét tekintjük át, különös figyelmet fordítva a közelmúlt legjelentősebb hozzájárulásának tekinthető ESPON (European Spatial Planning Observation Network) program keretei között létrehozott definíciókra és csoportosításokra. A második rész tartalmazza a tipológiát és egyben a turisztikai aspektusok bemutatását.

\section{AZ ESPON ELMÉLETI KERETE}

Az ESPON programban elsőként a városi/városkörnyéki terek általános jellemzése készült el. Ezeknek az alapfogalmaknak az ismerete nélkülözhetetlen a vizsgált határmenti jelenségek megértéséhez.

A morfológiai városi terület (MVT) település, vagy települések egybefüggő halmaza, amelynek népsürüsége meghaladja a $650 \mathrm{fö} / \mathrm{km}^{2}-\mathrm{t}$ és lakossága legalább 20000 fö. Ezek a küszöbértékek a területek objektív jellemzőinek megfigyelésével meghatározhatók. Egyébként ezek a magok szorosan kötödnek a $650 \mathrm{fö} / \mathrm{km}^{2}$-nél kisebb népsürüségü vagy 20000 fönél kisebb lakosságszámú, de az előzőekben definiálthoz kapcsolódó területekhez. Az összefüggőség vizuális ellenőrzésére a Google Earth, a Geoportal vagy a ViaMichelin térképészeti eszközeit használhatjuk. A több városi maggal rendelkező nagy agglomerációkat így csak akkor daraboljuk fel, ha a városi magok egyértelmü és egyedi identitással rendelkeznek, és morfológiailag elkülöníthetők. 
A funkcionális városi övezet (FVÖ) az előzőekben definiált morfológiai városi terület munkaerő vonzási körzetének felel meg. A becslés az ESPON 1.1.1 (policentrizmus) projektben készült, melyet az ESPON 1.4.3 projekt során - szükség szerint - korrigáltak. A FVÖ-k meghatározása - a lehetőségekhez képest - NUTS3 szintü területi egységeknek megfelelően történt. Ez a megközelítés lehetővé teszi a városok összehasonlítását gazdasági és funkcionális szempontból. Különösképpen alkalmas a legfontosabb városi központok elkülönítésére, azaz azoknak a nagy városoknak a meghatározására, amelyeknek valóban jelentős gazdasági ösztönző szerepük és olyan térszervező hatásuk van, amely túllép az alapszolgáltatások vagy minimális munkalehetőség biztosításán.

A lehatárolásokat követően a városokat a MVT és FVÖ lakosságának függvényében csoportosították. Így az alábbi megkülönböztetetések jöttek létre:

- MEGA: > 1 millió lakos (FVÖ)

- metropolisz: > 500 ezer lakos (FVÖ)

- poli-metropolisz: nagy agglomeráció, amely két egymástól legalább 60 km-re lévő központú érintkező vagy kisebb méretű várossal elválasztott MEGA-ból jött létre, vagy amely egymástól legalább 30 km-re található központú MEGA-ból és egy kisebb méretű városból jött létre.

- nagyváros: > 250 ezer lakos (FVÖ)

- középváros: $>150$ ezer lakos (FVÖ)

- kisváros: > 50 ezer lakos (FVÖ)

\section{A HATÁRON ÁTNYÚLÓ VÁROSI TEREK TIPOLÓGIÁJA}

$\mathrm{Az}$ előzőekben azonosított és osztályozott városokat, amennyiben határmenti fekvésủek, a határhoz való viszonyuk és nagyságuk szerint csoportosíthatjuk. Az ábrákon a nagyvárosokat négyzettel, a közepes és kisvárosokat körrel jelöltük, az őket szegélyező funkcionális városi övezeteket (FVÖ) pedig ferdén satírozva. Az államhatárt kettős vonal szimbolizálja.

Az elemzés során a turizmus két formáját emeljük ki, sötét színủ, folytonos nyillal jelöljük a helyi, jellemzően áruvásárlásra és szolgáltatások igénybevételére irányuló áramlást, míg világos színű, szaggatott nyíllal a nagyobb távolságról (zömében külföldről) kulturális vagy passzív szabadidős céllal érkező turistaáramlást. Természetesen a turizmus számos más formáját lehetne vizsgálni, de ezekre itt terjedelmi okok miatt nem térünk ki.

1. típus: ikervárosok, tipikusan kisméretűek, esetenként szerkezetileg egységes várost képezve, amelyet kettévág a határvonal. Mindegyiknek saját funkcionális övezete van, mégha van is tömegközlekedési összeköttetésük. A német-lengyel határon található GörlitzZgorzelec a legismertebb példa.

Az ikervárosok esetében mind a helyi turizmus, mind a nagyobb távolságról érkező nemzetközi turizmus jelen van. A helyi turizmus a két város között alakul ki általában, s leginkább bevásárlóturizmus jellemzi. A bevásárlóturizmus alapját a határ két oldalán fekvő két különböző országban alkalmazott eltérő árak biztosítják. A bevásárlóturizmus az alacsonyabb árak felé

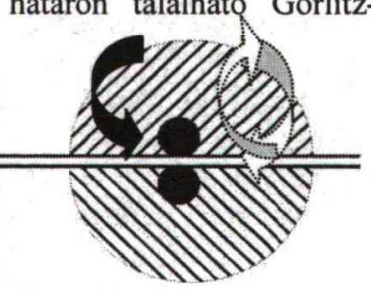
irányul. A turisták áramlása egy irányba addig tart, míg az árkülönbség a két oldal között fennáll. Az árak megváltozása esetén fordított irányú áramlás is bekövetkezhet, hiszen a turizmus ezen formája egyértemüen a gazdasági elönyök kihasználásáért történik. A nagy távolságról érkező, nemzetközi turizmusban résztvevőt érdekelheti akár a határ átlépése és a túloldalon levő árak összehasonlítása vagy egyszerủen a másik város kulturális értékei. A nemzetközi turizmus áramlása általában kétirányú, bármelyik irányból bármelyik irányba végbemehet. 
2. típus: nagyváros, amelynek morfológiai övezete folytatódik a szomszédos ország(ok)ban, a nagyváros funkcionális városi övezetében található kisvárosok, vagy összefüggő elővárosi övezet formájában. Tipikus példák Basel (Svájc, SaintLouis - Franciaország, Lörrach - Németország) vagy Genf (Svájc, Annemasse - Franciaország). Az együttmüködés kulcsfontosságú területe a közös tömegközlekedési hálózat megszervezése. Ez különösen a nem helyi kezelésben lévő szolgáltatók (például államvasút) esetében ütközhet jogi nehézségekbe is. Ideális esetben határon átnyúló szolgáltató vállalatok jönnek létre.

Ebben az esetben helyi turizmust nem elemezhetünk, hiszen a nemzetközi gyakorlatban a WTO definíció szerint a turista saját környezetét (lakó és munkahely) elhagyja. Tekintettel arra, hogy a kettes típusban a nagy és kisváros körüli tér nem válik szét a határ két oldalán két különböző funkcionális övezetre, a potenciális turista nem lép ki a funkcionális övezetböl, nem hagyja el szokásos környezetét. Nemzetközi turizmusa ennek a területnek jellemzően van, méghozzá az inkább a nagyvárosba érkezik elsődlegesen (több attrakció, esetleg nagyobb nemzetközi ismertség, több marketingmunka jellemezheti a nagysága miatt), de érkezőben esetlegesen átutazik/hat a kisvároson is. A nagyvárosból a kisvárosba csak akkor irányulhat jelentősebb nemzetközi turizmus, ha a kisváros olyan jelentős attrakciót birtokol, amelyért a nemzetközi turista mindenképpen ellátogat oda. Igen ritka az a helyzet, hogy a nagyváros közeli kisváros attrakciója képes legyen ugyanakkora vonzó hatást kifejteni a nemzetközi turizmusban résztvevőkre, mint a nagyváros vonzereje.

3. típus: nagyváros, amelynek morfológiai övezete nem folytatódik a szomszédos ország(ok)ban, a kisváros(ok)nak saját funkcionális városi övezetük van, és viszonylag kevesen ingáznak naponta a kisvárosból a szomszédos nagyvárosba. Ez a variáns kétségtelenül csökkenti a határon átnyúló szolgáltató vállalatok szükségességét. Általában a kisváros profitál a nagyvárosi

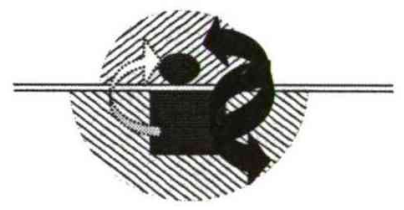
szolgáltatók közelségéből. A legjobb példa Strasbourg-Kehl.

Ebben az esetben egyértelműen erős a határ jelenléte, a nagyváros funkcionális városi övezetét képes megszakítani. A két különálló FVÖ garantálja, hogy a helyi turizmust is vizsgálni lehessen. A határ erös elválasztó jellege miatt a helyi turizmuson belül a bevásárlóturizmus mindenképpen fontos szerephez jut. A nemzetközi turizmus résztvevőinek határátlépése függ a helyi attrakciók nagyságrendjétől, a közös működtetésủ hálózatok meglététöl (pl. tömegközlekedés). Ha nincs szervezett tömegközlekedés a nagyváros és a szomszédos országban található kisváros között, akkor ez nagyon megnehezíti a nemzetközi turizmus áramlását, hiszen melyik turistának bérel autót ahhoz, hogy át tudjon menni a szomszédos, viszonylag közeli kisvárosba összehasonlítani az árakat vagy meglátogatni a másodlagos vagy harmadlagos attrakciókat?

4. típus: határon átnyúló morfológiai kis halmaz. A méretből adódóan a szervezési problémák sokkal kisebbek, mint a 2. típusnál. Ilyen például d'Esch-sur-Alzette (Luxemburg) - Audun-le-Tiche (Franciaország) vagy Longwy (Franciaország) - Pétange (Luxemburg) Aubange (Belgium)

Ebben az esetben nem vizsgálható helyi turizmus, hiszen a egyetlen funkcionális városi övezetről van szó. Az árak ez esetben általában teljesen azonosak a 
termékek/szolgáltatások tekintetében bármelyik országban. Csak egyes termékek (pl. benzin) ára miatt alakulhat ki bevásárlóturizmus nemzetközi szinten (tipikus példája Luxemburg esete). Ha a területen vannak turisztikai attrakciók, akkor azok a nemzetközi turizmus szempontjából érdekesek lesznek és a turisták egyiket a másik után sorra látogatják. A turisták gyakran azt sem tudják melyik országban vannak, kivételt képez ez alól, ha az országok különbözö pénznemeket használnak.

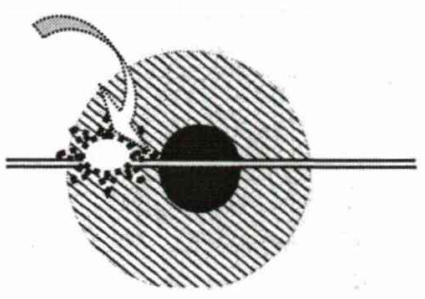

5. típus: nagyváros, amelynek funkcionális városi övezete folytatódik a szomszédos ország(ok)ban, amely akár saját másodlagos funkcionális városi övezettel rendelkező kisvárosokkal is tarkított lehet. Luxemburg nagyrégiója lehet jó példa. A határon átnyúló interakciók két legfontosabb területe a nagyváros elérhetősége a határ túloldaláról (munkaerőmozgás) és a küldő ország oktatási infrastruktúrájának fejlesztése, hogy a nagyváros munkaerő igényét ki tudja elégíteni.

Turisztikai elemzés szempontjából hasonlít a 4. típushoz. Ez esetben sem lehetséges a helyi turizmus elemzése az azonos FVÖ jelenléte miatt. Nemzetközi turizmus érkezik a területre, leginkább a metropoliszba vagy nagyvárosba. A nagyvárosban erős a turizmus, a környezö kisvárosokba ez a turizmus csak akkor irányul, ha a kisvárosoknak speciális vonzerejük van.

6. típus: a határ két oldalán fekvő két, szerkezetileg kapcsolódó nagyváros. Ilyen például Heerlen (Hollandia) és Aachen (Németország). Amennyiben határon átnyúló technikai együttmüködés szükséges, az magasabb területi szinten szerveződik. Ugyanakkor a városok viszonylag nagy jelentősége közös településmarketing kialakítására ösztönöz (kiegészítő funkciók). Az egymást kiegészítő FVÖ-k biztosítják, hogy a

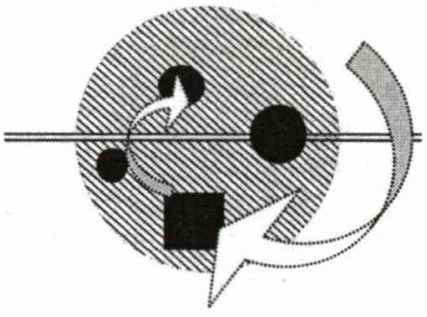
helyi turizmust is lehessen értelmezni. A bevásárlóturizmus

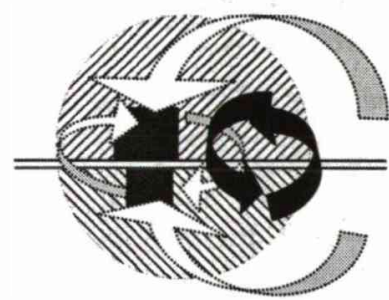
akár fontos méreteket is ölthet a helyi turizmus szintjén. Nemzetközi turizmus is létezik ebben az esetben: vagy az egyik vagy a másik városba érkeznek a turisták, de amennyiben lehetőségük van, a közös marketing hatására átlátogatnak a másik városba is. A viszonylagos közelség és az azonos méret, de különböző ország a városok esetében kettős hatást válthat ki: Szerencsés esetben felismerik a kiegészítés elvét, közösen lépnek fel a településmarketing segítségével, és így az egész határon átnyúló terület profitálhat a nemzetközi turizmus hatásaiból. A közösen üzemeltetett turisztikai desztinációmenedzsment szervezet szintén jó eszköz a turizmus szerepének növelésére. Amennyiben ez a közös promóció nem jön létre, akkor a turizmus esetleges lehet az egyik vagy másik oldalon.

7. típus: két nagyváros a határ két oldalán, amelyek szerkezetileg nem egységesek, csak a funkcionális városi övezeteik érintkeznek. Az előző típus egy variánsa, tipikus példája Bécs és Pozsony városa.

Ebben az esetben a nagyvárosok általában önmagukban is vonzó tényezők a helyi, belföldi turizmushoz. A helyi (belföldi) turisták általában csak az egyik

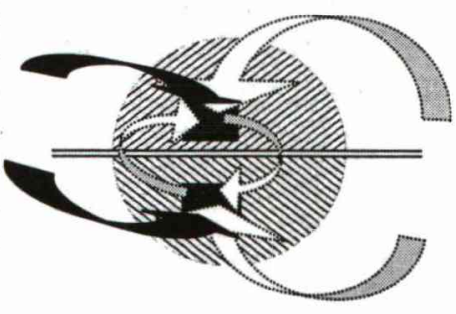


nagyvárost/metropoliszt látogatják meg, nem lépik át a határt. A nagy távolságból érkezỏ nemzetközi turisták (pl. kínai, japán, amerikai) várhatóan egymás után látogatják mindkét metropoliszt.

8. típus: egymáshoz viszonylag közel (nagyjából 50 km-re) fekvő nagyvárosok, amelyek funkcionális városi övezete legtöbbször nem is érintkezik. Ilyen például a HasseltGenk, Maastricht, Aachen és Liège városnégyes, vagy akár Hasselt-Genk és Eindhoven. Ha létezik is valamilyen együttmüködési szervezet, az csak konzultációs és alkalmi szerepet tölt be. A globális stratégiák igen hamar konkurrenciaharcba torkollanak, mert ahhoz kellően távol vannak egymástól a városok, hogy elkerülhető legyen az infrastruktúra közös használata. A nagy és magas színvonalú szellemi (egyetemek) vagy szolgáltató (kórházak) központokat a nemzeti szabályozások korlátozzák, így nem fogékonyabbak a határon átnyúló együttmúködésre, mint más, távolabbi intézményekkel való kooperációra.

Ebben az esetben csak szervezett turistacsoport látogatja meg mindkét települést egy szervezett út során, az egyéni turisták közül nagyon kevés, aki mindkét településen elidőzik. A bevásárlóturizmus abbban az esetben kaphat fontos szerepet, ha a két ország közötti termékek/szolgáltatások között jelentös árkülönbség van.

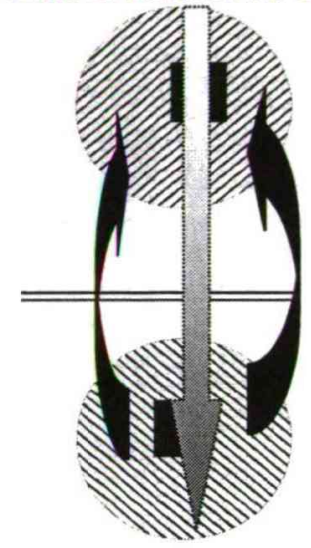

9. típus: nagyváros, amelyet kettévág a határvonal. Ennek példája volt a kettéosztott Berlin (Nyugat-Berlin funkcionális városi övezete hiányzott) vagy Nicosia (Ciprus). Viszontagságos politikai döntésekből adódó kivételes helyzetröl van szó, ahol határon átnyúló együttmüködés nem jön létre.

Ez a speciális politikai helyzet nem kedvez(ett) a helyi

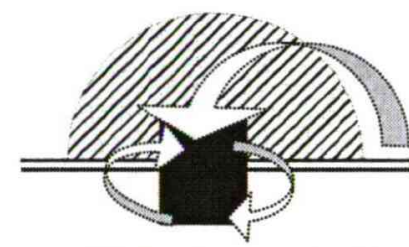
turizmus áramlásának, így az legálisan nem is jöhetett létre. A nemzetközi turizmus szintjén azonban már önmagában az a tény, hogy ilyen speciális helyzetủ város létezik, vonzza a turistákat. A határátkelés már önmagában turistaprogramként is megállja a helyét, de értéke többszörösére emelkedik, ha a határátkelö a helyiek elött zárva tart. A nemzetközi turizmusban résztvevő vendégek számára igen érdekes lehet a határ két oldalának összehasonlítása.

\section{3. ÖSSZEFOGLALÁS}

Amint azt már az előzőekben jeleztük a funkcionális városi övezet (FVÖ) a morfológiai városi terület munkaerő vonzási körzetének felel meg. Felmerül a kérdés, hogy ez a lehatárolás jó alapul szolgálhat-e a turizmus meghatározásának. A turizmusban a határok, határátlépés, a határ két oldalának ellentétes fejlettségének megtapasztalása mind-mind potenciális turistaprogramot jelenthet, akár kisvárosból indul a turista, akár nagyvárosból. Bizonyos turisztikai termékek függetlenek a város méretétől, (pl. fogorvosi szolgáltatás), megint mások viszont a város méretét fontos kritériumként kezeli (pl. klasszikus kulturális turizmus). 


\section{IRODALOMJEGYZÉK}

Baranyi Béla (2005): Az euroregionális együttmüködést szolgáló határközi struktúrák dilemmái Magyarországon. Selye János Egyetem, Révkomárom.

ESPON Project 1.4.3. (2006): Study on Urban Functions. Draft Final Report, Bruxelles.

Dövényi Zoltán (2002): A városok országhatárt átlépö kapcsolatai Magyarország szlovákiai és romániai határszakaszán. In: Szónokyné Ancsin Gabriella (szerk): Határok és az Európai Unió. Nemzetközi Földrajzi Tudományos Konferencia, SZTE TTK, Szeged.

Groupe de Travail Parlementaire Franco-Belge (2006): Bonnes pratiques de gouvernance dans les agglomerations transfrontalière en Europe. Paris.

Hardi Tamás (2001): Az egységes határrégiók kialakulásának feltételei - lehetséges határrégiók a Kárpát-medencében. Doktori értekezés, Györ-Pécs.

Nordregio (2005): ESPON 111. Potentials for polycentric development in Europe. Stockholm. 